\title{
МОНГОЛ ОРНЫ ЗАРИМ НУУРЫН ЭМЧИЛГЭЭНИЙ ШАВРЫН БАЛЬНЕОЛОГИЙН СУДАЛГАА
}

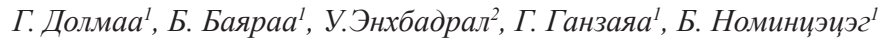

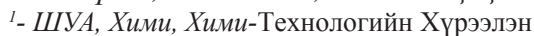 \\ Цахиммиудан: dolmaа_g@yahoo.com

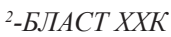

\begin{abstract}
The peloids are the important natural remedy all over the world. Balneological and physical properties of eight Mongolian peloids collected from Lake Khyaraan (Selenge province), Tushigtsagaan (Selenge province) and Nogoon (Gobi-Altai province), Lake Kholboolj (Bayankhongor province), Lake Khundagan (Tuv province), Lake Tsaidam and Nokhoi Unadag (Arkhangai province), Lake Gurvan nuur (Khentii province), have been studied using analytical techniques.

According the research we have determined physical properties of peloids from eight lakes (specific weight, moisture, porosity and moisture capacity) and balneological properties (liminess, thermal conductivity, heat capacity and the ability to retain heat) respectively. In result of the research, the physicochemical characteristics of the peloids are correcting standard satisfactory which treatment needs.
\end{abstract}

\section{ОРШИЛ}

1900 оноос А.Н.Покровскийн санал болгосноор Орост шавар эмчилгээг практикт өргөн хүрээнд хэрэглэх болсон бөгөөд ялангуяа Эх орны дайны үед хэрэглээ улам хүрээгээ тэлж шархадсан, тахир дутуу болсон хүмүүсийн эмчилгээнд нөхөн сэргээх чиглэлээр ихээхэн үр нөлөөтэй ашиглаж иржээ. Энэ үед лаг шавраас гадна Зөвлөлтийн нутаг дэвсгэр дээр тархсан хүлэр сапропель, зэрэг эмчилгээний шаврыг хэрэглэж эхэлсэн байна [1-6].

Шаврын эмчилгээний нөлөө нь химийн, биологийн болон дулааны шинж чанараар илэрхийлэгддэг. В.М.Боголюбовь болон В.Г.Олиференко нарын бүтээлд эмчилгээний шаврыг маш олон өвчинд хэрэглэдэг тухай дурдсан байдаг [7].

Эмчилгээний шаврын дулаан багтаамж, дулаан дамжуулалт, хөдөлгөөний эсэргүүцэл, дулаан барих чадвар, наалданги чанар, хольцын хэмжээ зэрэг нь хэрэглээний байдлыг урьдчилан төсөөлөхөд чухал ач холбогдолтой үзүүлэлтүүд юм.

Эмчилгээний шавар нь химийн янз бүрийн холбоогоор холбогдсон олон төрлийн нарийн нийлмэл бүтэц байгуулалт бүхий органик-органик бус нэгдлийг агуулдагаараа маш олон төрлийн шинж чанарыг агуулсан, анагаах увидастай байгалийн бүтээгдэхүүн юм.

\section{СУДАЛГААНЫ ОБЬЕКТ:}

Бид Сэлэнгэ аймгийн Хяраан, Түшиг цагаан, Говь-Алтай аймгийн Ногоон, Баянхонгор аймгийн Холбоолж, Төв аймгийн Хундаган, Архангай аймгийн
Цайдам, Нохой унадаг, Хэнтий аймгийн Гурван нуур зэрэг найман ордын эмчилгээний шаврыг судалгааны объект болгон ашигласан болно. 
Сэлэнгэ аймгийн Түшиг цагаан нуур: Сэлэнгэ аймгийн Цагаан нуур сумын ойролцоох Цагаан хөндийн тектоник хотост 680 м өндөрт орших нуур. Гадагш урсгалгүй

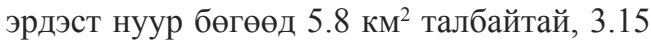
км урт, 2.7 км өргөн, эргийн шугамын урт 10.8 км. Хур бороотой жилд Бүтээлийн Хүжийнгийн нурууны өврөөс урсдаг жижиг горхи цутгадаг. Усны температур 7, 8 дугаар сард $18.6-20.1^{\circ} \mathrm{C}$ хүрэх ба ёроолдоо лаг шавартай. Эргэн тойрон намагтай, хэд хэдэн зэгстэй аралтай, нүүдлийн шувууд хуран цугладаг [8].

Сэлэнгэ аймгийн Түшиг цагаан нуур: Сэлэнгэ аймгийн Цагаан нуур сумын ойролцоох Цагаан хөндийн тектоник хотост 680 м өндөрт орших нуур. Гадагш урсгалгүй эрдэст нуур бөгөөд 5.8 км² талбайтай, 3.15 км урт, 2.7 км өргөн, эргийн шугамын урт 10.8 км. Хур бороотой жилд Бүтээлийн Хүжийнгийн нурууны өврөөс урсдаг жижиг горхи цутгадаг. Усны температур 7, 8 дугаар сард $18.6-20.1^{\circ} \mathrm{C}$ хүрэх ба ёроолдоо лаг шавартай. Эргэн тойрон намагтай, хэд хэдэн зэгстэй аралтай, нүүдлийн шувууд хуран цугладаг [8].

Сэлэнгэ аймгийн Хяраан нуур: Сэлэнгэ аймгийн Алтанбулаг сумын нутагт далайн мандлаас дээш 650 м өргөгдсөн газарт улсын хилээс 600 м зайтай оршдог. Нуур зууван хэлбэртэй, усны гадаргуугийн талбай 125000 м², гүн нь 0.5 м урсгалгүй, агаарын хур тунадас, газрын доорхи усаар тэжээгддэг [8].

Говь-Алтай аймгийн Ногоон нуур: Ногоон нуурыг ард түмэн Өмхий нуур хэмээн нэрлэдэг бөгөөд энэ нуур нь ГовьАлтай аймгийн төвөөс зүүн хойш 12 км зайд байрлах намагтай, өмхий үнэртэй нуур юм.

Баянхонгор аймгийн Холбоолж нуур: Холбоолж нуур нь баруун, зүүн гэсэн хоёр холбоо нуураас тогтдог. Зүүн нуур нь
Баянхонгор аймгийн Богд сумын нутагт 1330 м өндөрт оршдог, хүнсний давсыг орон нутгийн чанартай олзворлодог шорвог нуур юм. Энэ нуур нь 0.6 км² талбайтай, 1.2 км урт, 0.9 км өргөн, эргийн шугамын урт 4.0 км боловч усны төвшин тогтворгүй [8].

Төв аймгийн Хундаган нуур: Төв аймгийн Баян-Өнжүүл сумын нутагт өргөргийн $46^{\circ} 48^{6}$, уртрагийн $106^{\circ} 19^{6} 30^{6}$ солбицолд далайн төвшинөөс дээш 1400 м өндөрт оршдог. Энэ нуур нь ёроолдоо эрдэс давс бүхий ялзмаг шавартай бөгөөд хүхэрт устөрөгчийн үнэртэй лаг шаврыг арьсны болон үе мөчний өвчинд эрт дээр үеэс эхлэн ардын эмнэлэгт хэрэглэж ирсэн. Нуур нь хур бороо, гүний усаар сэлбэгддэг [8].

Хэнтий аймгийн Гурван нуур: Хэнтий аймгийн Дадал сумын нутаг, өргөргийн $49^{0} 2^{6} 30^{6}$, уртрагийн $111^{0} 39^{6}$ солбицолд, далайн мандлаас дээш 800 м өндөрт оршдог дунд нуурын шаврыг сонгон авсан болно [9].

Архангай аймгийн Цайдам нуур: Архангай аймгийн Өлзийт сумын төвөөс 30 км зайд орших Цайдамын хөндийд байдаг ижил нэртэй бүлэг нуурын хамгийн том нь юм. Хур бороо гүний усаар тэжээгддэг. 0.7 га талбайтай, 1.4 км урт, эргийн шугамын урт 3.6 км. Усны түвшин, гүн их өөрчлөгдөж, зарим жилд гүн нь 2 м хүрдэг, заримдаа бараг ширгэдэг. Манай орны хужиртай нуурын дотроос нүүрсхүчлийн натри хамгийн их агуулдаг, эрдэсжилт нь 159.47 г/л, химийн найрлагаараа карбонатын төрөлд багтдаг [9].

Архангай аймгийн Нохой унадаг нуур: Нохой унадаг нуур нь Архангай аймгийн Эрдэнэмандал сумын төвөөс баруун урагш 20 км зайтай уулс хоорондын хөндийд оршино. Баруун талаар Хануйн гол урсана. Нуурын хотгор нь сэвсгэр дөрөвдөгчийн хурдасаар хучигдсан. Нуурын ус нь саарал өнгөтэй, pH-9.8, эрдэсжилт 21.96 г/л байна. 


\section{СУДАЛГААНЫ АРГА ЗУЙ}

Эмчилгээний шаврын дээжийг Монгол улсын стандарт MNS 5848-2008 [10]ын дагуу авч шинжилгээнд бэлтгэсэн ба шаврын физик үзүүлэлтүүдийг жингийн аргаар, бальнеологийн Үзүүлэлтүүдийг А.Н.Бунеевын арга, Калориметрийн

\section{СУДАЛГААНЫ ҮР ДҮН}

Эмчилгээний шаврын физик механик шинж чанар. Судалгаанд 8 нуурын шаврын физик механик шинж чанар болох хувийн жин, гигроскоп чийг, багтаамжийн жин, сүвэрхэг чанар, хөдөлгөөний эсэргүүцэл, наалдамхай чанар, дулаан дамжуулалт, дулаан барих чадвар, хувийн дулаан арга, Кондратьевын аргаaр [9], шингээлтийн багтаамжийг иод шингээх титрийн арга, метилен хөх шингээх фотоэлектроколориметрын арга, спирт шингээх рефректометрын аргуудааар тус тус тодорхойлж судлав.

багтаамж зэргийг тодорхойлж үр дүнг хүснэгт 1-д харуулав. Нуурын янз бүрийн цэгээс авсан болон дундаж сорьцонд тодорхойлсон үзүүлэлтүүдийг практикт хэрэглэхэд зохимжтой дундаж хэмжээтэй харьцуулан үзүүллээ.

Хуснэгт 1

Эмчилгээний шаврын физик ба бальнеологийн ҮзүҮлэлтүҮд.

\begin{tabular}{|c|c|c|c|c|c|c|c|c|c|c|}
\hline \multicolumn{2}{|c|}{ Шаврын ордын нэр } & 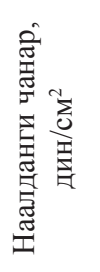 & 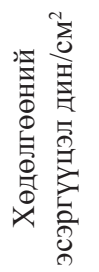 & 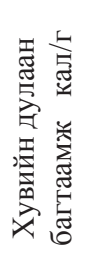 & 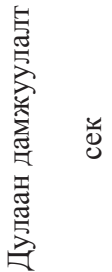 & 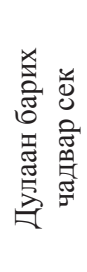 & 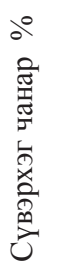 & 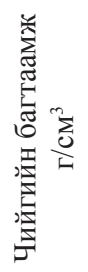 & 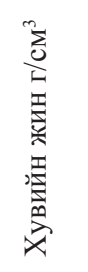 & 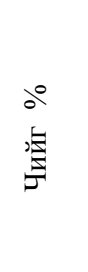 \\
\hline \multicolumn{2}{|c|}{$\begin{array}{c}\text { Шаврын хэрэглээнд } \\
\text { зохимжтой байх } \\
\text { дундаж үзүүлэлт } \\
\text { [10] }\end{array}$} & $\begin{array}{r}4000- \\
14600\end{array}$ & - & 0.4-08 & & $\begin{array}{r}350- \\
1000\end{array}$ & & - & $\begin{array}{r}1.01- \\
1.8\end{array}$ & 20-95 \\
\hline \multirow{4}{*}{ 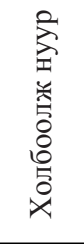 } & Баруун хойд & 3471 & 6407 & 0.89 & 0.073 & 14.1 & 17 & 1.6 & 1.91 & 19.6 \\
\hline & Урд & 2950 & 1325 & 0.41 & 0.021 & 47.6 & 34 & 1.4 & 2.10 & 24.9 \\
\hline & Баруун урд & 1041 & 2209 & 0.52 & 0.033 & 30.3 & 10 & 1.8 & 1.99 & 22.9 \\
\hline & Хойд & 3158 & 3977 & 0.63 & 0.053 & 18.8 & 11 & 1.76 & 2.01 & 20.1 \\
\hline \multirow{3}{*}{ 睎窔 } & Урд & 1006.6 & 15466 & 0.59 & 0.045 & 22.2 & 5 & 1.7 & 1.78 & 36.5 \\
\hline & Хойд & 3992 & 20889 & 0.88 & 0.024 & 41.6 & 11 & 1.5 & 1.68 & 63.1 \\
\hline & ЗҮYн & 5033 & 8837 & 0.68 & 0.063 & 15.8 & 6 & 1.7 & 1.60 & 55.6 \\
\hline
\end{tabular}




\begin{tabular}{|c|c|c|c|c|c|c|c|c|c|c|}
\hline \multirow{5}{*}{ 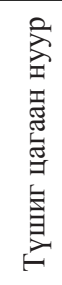 } & Баруун & 8738.1 & 30932 & 0.81 & 0.021 & 56.0 & 16 & 1.26 & 1.50 & 49.2 \\
\hline & Урд & 11108 & 41979.7 & 0.50 & 0.014 & 71.0 & 13.8 & 1.42 & 1.66 & 43.9 \\
\hline & Баруун урд & 7984 & 66283.7 & 0.72 & 0.031 & 37.0 & 9.5 & 1.34 & 1.48 & 55.3 \\
\hline & Хойд & 4165.6 & 4418.9 & 0.70 & 0.020 & 50 & 13.5 & 1.4 & 1.62 & 45.9 \\
\hline & дундаж & 4559.7 & 6407.3 & 0.69 & 0.031 & 33.3 & 14.3 & 1.3 & 1.51 & 52,0 \\
\hline \multirow{5}{*}{ 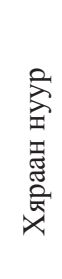 } & Баруун хойд & 4859.8 & 5523 & 0.70 & 0.062 & 22.72 & 28.3 & 1.44 & 2.01 & 27.2 \\
\hline & Хойд & 3818.4 & 3314 & 0.60 & 0.039 & 31.2 & 21.8 & 1.55 & 1.98 & 20.5 \\
\hline & ЗүҮн & 5207 & 3756 & 0.44 & 0.034 & 25.6 & 29.6 & 1.36 & 1.94 & 23.9 \\
\hline & Урд & 4686,3 & 5523.6 & 0.62 & 0.028 & 45.4 & 38.3 & 1.24 & 2.02 & 26.2 \\
\hline & дундаж & 3471 & 4418 & 0.64 & 0.013 & 23.5 & 29.4 & 1.28 & 1.82 & 28.4 \\
\hline \multirow{5}{*}{ 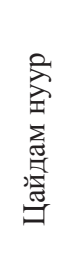 } & Баруун & - & 21437.4 & 0.80 & 0.036 & 32.7 & - & - & 1.51 & 48.8 \\
\hline & Хойд & - & 15873.5 & 0.31 & 0.019 & 26.8 & - & - & 1.67 & 38.4 \\
\hline & ЗҮҮн & - & 22140.7 & 0.52 & 0.024 & 33.4 & - & - & 1.55 & 44.9 \\
\hline & Урд & - & 18689.6 & 0.49 & 0.025 & 35.2 & - & - & 1.86 & 37.2 \\
\hline & дундаж & - & 16837.0 & 0.66 & 0.038 & 27.2 & - & - & 1.59 & 45.1 \\
\hline \multicolumn{2}{|c|}{ Нохой унадаг нуур } & - & 19756.6 & 0.57 & 0.310 & - & - & - & 1.68 & 39.2 \\
\hline \multicolumn{2}{|c|}{ Ногоон нуур } & 4161 & 2651.3 & 0.57 & 0.032 & 28.6 & 24 & 1.22 & 1.61 & 35.8 \\
\hline \multicolumn{2}{|c|}{ Гурван нуур } & - & 7357.5 & 0.55 & - & 47.0 & - & - & 1.26 & 73.6 \\
\hline
\end{tabular}

Эмчилгээний шаврын хөдөлгөөний эсэргүүцэл, наалданги чанар нь тэдгээрт харилцан адилгүй агуулагддаг органоколлоидны хэсэг, шаварлаг эрдэс, бусад бүрдүүлэгчид болон физик-химийн хүчин зүйлүүдээс хамаардаг. Нуурын янз бүрийн байрлал дахь шаврын шинж чанарыг тодорхойлох нь илүү практик ач холбогдолтой юм. Нуурын шаврын ерөнхий шинж чанарыг тогтоохдоо тусгайлан бэлтгэсэн дундаж дээжинд судалгааг явуулдаг.

Эмчилгээний шаврын хөдөлгөөний эсэргүүцэл их байхад наалданги чанар мөн адил их байдаг. Хундгана нуурын урд тал болон хойд тал, Түшиг цагаан нуурын баруун, урд, баруун урд талуудын хөдөлгөөний эсэргүүцэл болон наалданги чанар хоёр нь хоорондоо ихээхэн ялгаатай гарсан байна. Энэ нь нуурын шавар бүрэлдэн бий болж байгаа газрын гүний болон хөрсний геологийн хурдас хуримтлал болон ус ургамлын байдлаас хамаарч байгаа хэрэг юм.

Наалданги чанар хэт бага байвал эмчилгээнд хэрэглэх үед мэдрэлийн хүлээн авууруудад нөлөөлөхдөө харьцангуй учир дутагдалтай байх талтай бөгөөд манай нууруудын эмчилгээний шаврын хөдөлгөөний эсэргүүцэл болон наалданги чанарын хувьд эмчилгээнд хэрэглэхэд тохиромжтой нь хүснэгтээс харагдаж байна.

Судалгаанд хамрагдсан бүх ордын шавар нь хувийн дулаан багтаамжаараа эмчилгээнд хэрэглэхэдшаардагдах стандарт хэмжээтэйгээ тохирч байна. Эмчилгээний шаврын дулаан дамжуулалт нь 0.014-0.073 секунд, дулаан барих чадвар нь 14.1-71.0 секундын хооронд байна. Үүнээс Холбоолж нуурын баруун хойд талын дулаан дамжуулалт 0.073 секунд байхад, дулаан барих чадвар нь 14.1 секунд, Түшиг цагаан нуурын урд талын дулаан дамжуулалт 0.014 секунд, дулаан барих чадвар нь 71.0 
секунд байгаа нь эмчилгээний шаврын дулаан дамжуулалт болон дулаан барих чадвар нь урвуу хамааралтай хэмжигдэхүүн гэдэг нь харагдаж байна. Эдгээр нууруудын эмчилгээний шаврын дулаан барих чадвар нь олон улсын ангиллын хэмжээнд тогтоосон үзүүлэлтээс маш бага байгаа нь практикт хэрэглэхдээ тусгайлан анхаарах шаардлагатайг харуулж байна. Эмчилгээний шаврын дулаан барих чадвар их байвал эмчилгээнд илүү үр дүнтэй байдаг.

Судалгаанд авсан нууруудын янз бүрийн цэгээс авсан шаврын физик механикийн үзүүлэлтүүд нь өөр хоорондоо багагүй ялгаатай байгаa нь тэдгээрийн химийн найрлага, эргэн тойронд байгаа ургамалжилт, хурдас хуримтлалын ялгаатай байдалтай холбоотой юм.

\section{Эмчилгээний шаврын шингээх}

чадвар. Шаврыг жижиглэж устай аяганд хийхэд хөвж байвал шингээх чадвар сайтай байна гэж үзнэ. Эмчилгээний шаврын иод, метилен хөх, этилийн спирт шингээх чадварыг тодорхойлж, дүнг хүснэгт 2-4-т харуулав.

Этилийн спирт шингээх чадвар. Этилийн спиртийн $96.0 ; \quad 86.4 ; 76.8$; $67.2 ; 57.6 ; 48.0 ; 38.4 ; 28.8 ; 19.2 \%$ \%-ийн концентрацитай уусмал бэлтгэж, тэдгээрээс дундаж концентрацитай уусмалаар гэрэл шүүгчийг сонгоно. Дараа нь сонгосон гэрэл шүүгч дээр бүх уусмалын хугарлын илтгэгчийг рефректометрээр хэмжиж хэмжилтийн дүнгээр жиших муруй байгуулна. Үүний дараа 1 г нунтагласан (эмчилгээний шавар) шингээгч авч тэдгээрийг 5 мл 1-р уусмалд хийж 30 минут соронзон хутгуур дээр хутгана. Үүний дараа уусмалыг центрфугт эргүүлэх замаар хатуу шингэн фазыг ялгаж цэвэр уусмалаар нь авч хугарлын илтгэгчийг хэмжинэ. Хэмжсэн хугарлын илтгэгчийг ашиглан уусмалын концентрацийг жиших муруйн тусламжтайгаар олж, адсорбцилогдсон бодисын хэмжээг олж харьцуулан дүгнэлт өгнө. Шаврын спирт шингээх чадварыг тодорхойлсон үр дүнг 2-р хүснэгтэнд харуулав.

Хуснэгт 2

Этилийн спирт шингээх чадвар

\begin{tabular}{|c|c|c|c|c|c|}
\hline Дээжийн нэр & $\begin{array}{c}\text { Этилийн спиртийн } \\
\text { анхны, концентраци, } \\
\mathrm{C}_{1} \%\end{array}$ & $\begin{array}{c}\text { Шингээлтийн } \\
\text { хугарлын } \\
\text { илтгэгч, } \mathrm{n}\end{array}$ & $\begin{array}{c}\text { Жиших муруйгаас } \\
\text { олсон концентраци } \\
\mathrm{C}_{2} \%\end{array}$ & $\mathrm{C}_{1}-\mathrm{C}_{2}$ & $\begin{array}{c}\text { Шингээг- } \\
\text { дсэн, \% }\end{array}$ \\
\hline Ногоон нуур & 96 & 1,367 & 89,5 & 6,5 & 6 \\
\hline Хяраан нуур & 96 & 1,365 & 76,8 & 19,2 & 20 \\
\hline Цагаан нуур & 96 & 1,366 & 86,4 & 9,6 & 10 \\
\hline
\end{tabular}

Хүснэгт 2-оос харахад хамгийн их этилийн спиртыг шингээх чадвартай шавар нь Хяраан нуур (20\%), Түшиг цагаан нуур $(10 \%)$, Ногоон нуур (7\%) тус тус шингээсэн байна.

Метилен хөх шингээх чадвар. 50 мл 10 ш хэмжээт колбонд брютек ашиглан 2.5, $3.75,6,7.5,9,9.75,11.25,13.5,15,17.25$ $\mathrm{cm}^{3}\left(500 \mathrm{мг} /\right.$ дм$\left.^{3}\right)$ концентрацитай метилен хөхийн уусмал хийж хуваарь хүртэл нь нэрмэл усаар дүүргэнэ. Метилен хөхийн эдгээр уусмал нь 50, 75, 120, 150, 180, 195, $225,270,300,345$ мг/дм ${ }^{3}$ концентрацитай уусмалууд болно. Эдгээр уусмалын оптик нягтыг 10 мм-ийн кювет ашиглан хөх гэрэл шүүгч дээр оптик (А) нягтыг хэмжинэ. Гарсан үр дүнгээр $\mathrm{A}=\mathrm{f}(\mathrm{C})$ хамаарлын график байгуулна. Дараа нь 1.5 гр эмчилгээний шавар жигнэн авч 25 мл 120 мг/дм ${ }^{3}$ концентрацитай уусмал хийж соронзон хутгуур дээр 30 мин хутгана. Уусмалыг центрфуг, цаасан шүүдтүүр ашиглан шүүж, шингээсний дараах уусмалын оптик нягтыг хэмжинэ. Түүнийг ашиглан шингээлтийн оптик нягтыг олж, түүний тусламжтайгаар шингээх чадварыг тодорхойлно. Үр дүнг хүснэгт 3-т харуулав. 
ХУснэгт 3

Метилен хөх иингээх чадвар

\begin{tabular}{|c|c|c|c|c|c|c|}
\hline \multirow{2}{*}{ Дээжийн нэр } & \multirow{2}{*}{$\begin{array}{c}\text { Метилен хөхийн } \\
\text { шингээхээр авсан, } \\
\text { конц, } \mathrm{C}_{0} \text { мг/дм }\end{array}$} & \multirow{2}{*}{$\begin{array}{c}\text { Шингээл- } \\
\text { тийн нягт, } \\
\text { А }\end{array}$} & \multirow{2}{*}{$\begin{array}{c}\text { Жиших } \\
\text { муруйгаас } \\
\text { олсон конц, C }\end{array}$} & \multirow{2}{*}{$\mathrm{C}_{0}-\mathrm{C}_{1}$} & \multicolumn{2}{|c|}{$\begin{array}{c}\text { Шингээгдсэн } \\
\text { хэмжээ } \\
\end{array}$} \\
\hline & & & & & $\%$ & $\mathrm{a}, \mathrm{M \Gamma} / \Gamma$ \\
\hline Ногоон нуур & 120 & 0.15 & 20 & 100 & 16.6 & 0.6 \\
\hline Хяраан нуур & 120 & 0.12 & 17 & 102 & 14.6 & 0.5 \\
\hline Цагаан нуур & 120 & 0.07 & 10 & 110 & 8.3 & 0.5 \\
\hline
\end{tabular}

Хүснэгт 3-аас харахад метилен хөхийг Ногоон нуур, Хяраан нуур, Түшиг цагаан нуурын шавар харгалзаагаар 16.6\%, 14.6\%, $8.3 \%$ тус тус шингээсэн байна.

Метилен хөх, иод, этилийн спирт зэрэг нь эмчилгээний шаврын гадаргуу дээрх нүх сүвэнд нь, харин ионууд нь эмчилгээний шаврын бүтцэнд нь шингээгддэг. Эмчилгээний шаврын шингээх чадварын дүнг нэгтгэн хүснэгт 4-т харуулав.

ХУснэгт 4

Эмчилгээний шаврын шингээх чадвар

\begin{tabular}{|c|c|c|c|}
\hline Дээж & Метилен хөх шингээх, \% & Иод шингээх, \% & Этилийн спирт шингээх, \% \\
\hline Ногоон нуур & 16.6 & 11.2 & 7 \\
\hline Хяраан нуур & 14.6 & 15.7 & 20 \\
\hline Түшиг цагаан нуур & 8.3 & 8.7 & 10 \\
\hline
\end{tabular}

Судалгаанд авсан нууруудын эмчилгээний шаврын гадаргуу дээр метилен хөх 8.3-16.6\%, иод 8.7-15.7\%, этилийн спирт 7-20 \% тус тус шингээгдсэн байна. Хяраан болон Ногоон нуурын шавар метилен хөх $(14.6 \%, 16.6 \%)$, иод

\section{ДҮГНЭЛТ}

Судалгаанд 8 нуурын эмчилгээний шаврын хувийн жин, гигроскоп чийг, чийгийн багтаамж, сүвэрхэг чанар зэрэг физик үзүүлэлт, хөдөлгөөний эсэргүүцэл, наалдамхай чанар, дулаан дамжуулалт, дулаан барих чадвар, хувийн дулаан багтаамж зэрэг бальнеологийн үзүүлэлтүүдийг тодорхойлоход нийтдээ эмчилгээнд хэрэглэх стандарт хэмжээтэй (15.7\%,11.25\%)-ыг илүY шингээж байгаа бол, Хяраан нуурынх этилийн спиртийг $(20 \%)$ илүү шингээж байна. Харин Түшиг цагаан нуурын шаврын метилен хөх (8.3\%), иод $(8.7 \%)$, спирт $(10 \%)$ шингээх чадвар харьцангуй бага байна.

тохирч байна.

Эмчилгээний шаврын шингээлтийн хувь нь Хяраан >Ногоон> Түшиг цагаан гэсэн дараалалтай байгаа нь эдгээр нуурын шаврын сүвэрхэг чанарын үзүүлэлтэй шууд хамааралтай байгаа ба эдгээр судалгааны үр дүн бие биеэ баталгаажуулж байгааг харуулж байна. 


\section{Ашигласан бүтээлийн жсагсаалт}

1. Иванов В.В.,Малахов. Л.М., Материаль поизучению лечебных грязей озер и месторождений / "Мир” М.: 1963. 228 с.

2. Бахман В.И., Овсяникова К.А., Методика анализ лечебных грязей пелоидов. Москва.: 1965. $127 \mathrm{c}$.

3. Под.ред.проф. Данилов Ю.Е., и Царфис П.Г.,Справочник покурортологии и курортотерапии / "Медииина" М.: 1973. 67-77 c.

4. Царфис П.Г., Киселев В.Б., “Лечебные грязы и природные теплоносители” М.:1990, изд.во "Высшаяшкола", $12 \mathrm{c}$.

5. Материалы вессоюзногосим позиумаповопросам разведки, изучения курортногоисп.я минеральныхвод и лечебных грязей. Москва.:Профиздат $1983.204 \mathrm{c}$.

6. Под. ред. Александрова. В.А., Иванов. В.В., Сборник работ погидрогеологии, физикохимии и микробиологии минеральных вод и лечебных грязей и климату. -М., "Медгиз" $1955-367 \mathrm{c}$

7. Бальнеологическое средство “ГЛИНОФИТ” для лечение и профилактири различных заболеваний (реферат) . СССР, 2006

8. Ж. Цэрэнсодном Монгол орны нууруудын католог УБ. 2000, 141 х.

9. . Долмаа “Эмчилгээний шавар байгалийн гайхамшигт бүтээгдэхүүн” УБ. 2012

10. MNS 5848-2008 “Эмчилгээний шаврын ангилал. Техникийн шаардлага” 